Article

\title{
Sequent Occupance and Toponymy in Singapore: The Diachronic and Synchronic Development of Urban Place Names
}

\author{
Francesco Cavallaro ${ }^{(D}$, Francesco Perono Cacciafoco* ${ }^{\mathbb{D}}$ and Zhi Xuan Tan \\ Linguistics and Multilingual Studies, School of Humanities, Nanyang Technological University, Singapore \\ 639818, Singapore \\ * Correspondence: fcacciafoco@ntu.edu.sg; Tel.: +65-651-483-95
}

Received: 21 July 2019; Accepted: 30 August 2019; Published: 3 September 2019

check for updates

\begin{abstract}
This paper is aimed at investigating the applicability of the notion of Sequent Occupance to the Singapore context. Sequent Occupance as a phenomenon in Human Geography was first theorized by Derwent Whittlesey in 1929 in order to describe the current cultural landscape of a region as a combination of all the people which have 'sequentially' occupied that region from the past to the present. According to the Sequence Occupance Theory, the cultural imprint of each civilization is never completely lost and its traces can be seen to the present day. This is a historical phenomenon that occurs in the same region or space, but at different times. Sequent Occupance regards each region as a pattern of many cultural layers laid upon each other, where each layer can be attributed to a particular civilization or culture, which overlaps the ones before it. Singapore, with its multilingual and multicultural context and with its colonial past, is a very important test-bed for Sequence Occupance approaches both in the fields of Historical Toponomastics and Human Geography. This paper aims to apply the notion of Sequence Occupance to the study of Singapore Toponomastics with a focus on Odonymy and Micro-Toponyms. The study discusses the notion of Sequent Occupance in Singapore in the light of several local Toponyms, trying to ascertain if this concept can be applied to the diachronic and synchronic development of the Urban Toponymy of the Lion City. The article also highlights historical processes in the "making" of the multi-layered Singapore society.
\end{abstract}

Keywords: Singapore; sequence occupance; toponymy; historical toponomastics; historical geography

\section{Sequent Occupance}

Cultural Ecology is an important sub-discipline within Human Geography. Stemming from anthropological studies concerned over how human societies are affected by changes to the environment they live in, Cultural Ecology is the "theoretical perspective common to cultural geography and derived from anthropology that focuses on the relationship between human activity and environmental conditions." [1] (p. 282). This sub-discipline had its most influential figure in Carl Sauer (1889-1975) who, in his seminal work The Morphology of Landscape, called for a more refined approach to the study of the impact humans have on the environment. Sauer applied a cyclical idea to Geography according to the notion of "landscape-as-history" rather than the "landscape-as-nature" approach [2] (p. 36). According to Denevan [2] (p. 36), "Sauer transferred Spengler's line of thought about the cyclical nature of civilizations to the landscape. In that line of thinking, each place (i.e., landscape) formed a stage on which a succession of different cultures through time had left subtle traces on the land as in a palimpsest."

Hanks [1] (p. 254) summarized Sauer's thoughts in "that cultures are the unique result of a collection of influences, but especially are shaped by those cultural patterns that were previously 
present in the landscape." Hanks goes on to say that "Sauer became the most influential figure in American cultural geography, and his emphasis on a particularist approach to the study of landscapes remains at the heart of the discipline today" [1] (p. 254; for an exhaustive review of Sauer's work, see [3]).

An important component of Cultural Ecology is the concept of Sequent Occupance. Whittlesey, strongly influenced by Sauer's teachings, proposed that

In fact, the distribution of people and of their activities over the surface of an earth of varied forms, conditions, and resources, is conceded to be the major premise of anthropogeography, human geography, or chorology, as it is variously called. These spatial concepts remain purely descriptive, however, unless they are treated dynamically, i.e., unless the time factor is cognized. The view of geography as a succession of stages of human occupance establishes the genetics of each stage in terms of its predecessor. [4] (p. 162)

Hanks [1] (p. 306) defines Sequent Occupance as "the notion that landscapes are shaped over time by the sequential settlement, or at least sequential use, of that landscape by various groups who occupy the land. Thus, according to the proponents of this approach to landscape study, a place can be understood only through an examination of the historical impact of such occupation, and a comprehension of the nature of the culture at each stage of occupation."

Hanks [1] (p. 307) also recognizes the importance of Sequent Occupance in Historical Geography and that "in some cases the historical patterns of settlement of a place may be partially revealed through a study of the local toponymy, which frequently carries clues to the history of previous cultural occupants as well as to a place's former function on the landscape." Meyer [5] is among the first researchers to highlight the significance of Toponymy in Sequent Occupance studies. In his article on the place names of the Calumet region in Northwest Indiana-Northeast Illinois, he states: "There occurred to us the idea that a toponomic (sic) study might take on increasing geographic significance if we attempt a partial chronologic-chorographic treatment of place names in addition to merely identifying place nomenclature, thus contributing to our knowledge of the progress of regional settlement and economic development." [5] (p. 142).

It "occurred" to us as well that a study of Singapore's Toponymy might contribute to the expanding knowledge of the history of this small island state.

\section{Sequent Occupance and Singapore}

The toponyms associated with its name over its history reflect Singapore's Sequent Occupance context. The names manifest a continuous Malayic occupance from (perhaps) as early as the 3rd Century $\mathrm{CE}$, with varied influences by the major political players in the region, Sumatran, Javanese, Indian, etc. until the arrival of the Europeans and the British, who established a settlement that led to the multilingual and multi-ethnic metropolis of today.

Hsü Yün-ts'iao (Xǔ Yúnqiáo) [6] claims to have uncovered the term Pulau Ujong. He claims it to be "the oldest name for Singapore" (p. 9) in the accounts of the voyages by Blazon Officer Chu Ying (Zhū Yìng) (宣化從事朱應) and Adjutant Kāng Tài (中郎康泰), who were sent on a mission to the South Seas by General Lü Tai (Lü Dài) (呂岱) of the Wú Kingdom (吳國), who was the Governor-General of Canton and Vietnam at around $231 \mathrm{CE}$. In these accounts, Hsü Yün-ts'iao came across two refences to $P^{\prime} u$-lo chung (Púluō zhōng) (蒲羅中) and P'u-lo chung ((Púluō zhōng guó) state (蒲羅中國). Hsü Yün-ts'iao goes on to affirm that " $P$ ' $u$-lo chung - The earliest name of Singapore in remote days, and should correspond to Pulau Ujong in Malay, the island on the extremity of the peninsula. It reminds us of Johor's old name, Ujong Tanah, "the extremity of land". Therefore, Púluō is the transliteration of the Malay word pulau "island" and chung corresponds to ujong." (p. 9).

Historical records tell of a place originally named Temasek or Temasik. Wang Dayuan, a Chinese traveller, chronicled his voyages in the 1300s [7] and visited the island at around 1330. He referred to it as Dānmǎxī (單馬錫). Hsü Yün-ts'iao (Xǔ Yúnqiáo) [6] reports the name in Wang Dayuan's chronicles 
as Tan-Ma-Hsi (單馬錫) and states that the same term “also appeared in Cheng Ho's chart (鄭和航海圖 Cheng-ho hang-hai t'u [Zhèng Hé hánghăi tú]) given in Mao Yüan-yi's (Máo Yuányí) (茅元儀) Wu pei chih (Wǔ bèi zhì) (武備志), volume 240, with the same pronunciation, but with different characters, as 淡馬錫 (Tan-ma-hsi/Tànmăxī), which in Hokkien pronunciation is Tam-ma-siak and more nearly corresponds to Tumasik." [6] (p. 1). Gerini [8] points out, though, that "hsi" could refer to "tin" and to a combination of the Malay tanah "land" with Chinese hsi (xī) "tin", literally "land of tin" (see also [9]).

The origin of the name Temasek is unclear. In his Malay-English Dictionary that R.J. Wilkinson published in 1910, he suggests that Temasek probably derives etymologically from tasek, a Malay word for "sea" or "lake". With the insertion of the infix -em-, the term could be translated as "place surrounded by the sea" [10] (p. 183). This name also appears as Tumasik in the Javanese epic Nagarakretagama. The poem is written in Old Javanese and describes the Majapahit Empire in its prime. One other possible explanation is that it was named after one of the Srivijaya Kings, Maharaja Tan Ma Sa Na Ho, who acceded the throne of Srivijaya in 1376 [11]. Hsü Yün-ts'iao [6], on the other hand, suggests that the toponym could be a Greek loan word, a corruption of Damascus ( $\Delta \alpha \mu \alpha \sigma \kappa o ́ s)$, which would have the meaning of "a well-watered land".

Dates are difficult to ascertain, but the Sejarah Melayu, "The Malay Annals", a Malay literary work composed sometime between 15th and 16th centuries, tell of Sri Tri Buana, a Srivijayan prince from Palembang who travelled to Temasik with his Chief Minister Demang Lebar Daun and, while hunting at Kuala Temasik "the mouth of the Temasik River" (in the place now known as the Padang; this seems to be the first reference to the Singapore River), saw an unfamiliar animal. Demang Lebar Daun observed that, based on what he had heard, the animal was a lion. At this point, Sri Tri Buana decided to establish a city at Temasik and call it Singapura, or "Lion City" [10] (p. 150). Chronologically, Gerini [8] places this event at around 1284. This "is, of course, far more ornate and glowing, quite in the style that suits native fancy" [8] (p. 506). Gerini, therefore, argues for:

the early presence on the island of immigrants from a country-whether the Malay Peninsula, Sumatra, or Java - that had received Indu civilization; and that temple (see the section on Fort Canning below) may have been the pura or puri that received the name of Simha ("lion") and caused the neighbouring village to be called therefrom Simhapura. (Majumdar does mention, for example, that "Simhapura was the capital of a Kalinga kingdom even as late as the twelfth century AD" [11] (p. 6). This city is in the current Indian state of Telangana and is now known as Singapuram). Such a designation was doubtless adopted either with a view to enhance the prestige of the foundation by naming it after an old city of India, or to perpetuate, as often occurred in many parts of Indo-China, the name of the founder, which may just have been Simha. [8] (p. 506).

Borschberg [12] presented an exhaustive list of possible variations of the name across the last four centuries or so. The name, Singapura was "anglicised" to Singapore in the 1800s.

A 1604 map by the Malay-Portuguese cartographer Manuel Godinho de Erédia [13] displays the name xabandaria. Borschberg [14] (p. 383) says that this means the port of Singapore at that time was active enough to have a shahbandar on the island (Shahbandar is Persian for "King of the Haven" and a more apt English equivalent is "Harbour Master") [15] (pp. 517-533). The Flemish merchant Jacques Coutre, in the early 1600s, recorded visiting the "Ysla de la Sabandaria Vieja" or "Island of the Old Shahbandaria". Borschberg [15] claims this is a name for Singapore.

Miksic [10] highlights how archaeological studies have shown that Singapore became an important port in the 1300s and maintained an advanced level of prosperity over the 14th century. Abshire [16] documents a variety of accounts of this prosperous period. While the settlement declined in influence through the 15th Century, it was still an important port well into the 17th Century [14]. Abshire [16] posits that the decline of Singapura in the 15th Century was due to the development of the stronger Kingdom of Melaka at that time. 


\section{Recognized Stages of Sequent Occupance in Singapore}

Archaeological and other historical evidence points to a Malay settlement existing in Singapore in the 1300s. Miksic [10] points out that

Information on ancient Singapore after 1400 is less comprehensive than for the fourteenth century, but we can use the little data we have to build a general picture of the settlement during the period of the Melaka sultanate and its successors in Johor and Riau up to about 1600. After a hiatus of about 200 years, Singapore revived when a new settlement was founded around the river mouth in 1811, followed by the start of the colonial period in 1819 . While the archaeology of nineteenth- and early-twentieth-century Singapore is a separate topic, comparisons between precolonial and colonial Singapore show how life in a port with a sizeable overseas Chinese community differed between two eras separated by 500 years. (p. 22)

The 15th Century saw the arrival of European colonial powers in South East Asia. The most prominent of these, at that time, were the Portuguese, who conquered Melaka in 1511 [16]. During the next 100 years or so, Singapore is repeatedly mentioned in the chronicles of various travellers, and is referred to as a "'kingdom," but one with very little territory." [16] (p. 27). After a century of Portuguese presence and of various conflicts involving Aceh (Sumatra) and Johor groups, the next big players to arrive in South East Asia were the Dutch in the early 1600s. The next 200 years witnessed varying fortunes in the region for the Portuguese, the Dutch, the Johor Kingdom (also known as the Johor Empire, the Johor Sultanate, Johor-Riau, Johor-Riau-Lingga, was a Malay kingdom which lasted from 1528 to 1855; the kingdom, in its most powerful stages, controlled today's Johor, Riau, Lingga, and much territory of southern Peninsula Malaysia, including Singapore, plus other islands off the east coast of the peninsula), and the Bugis (who were people originally from the island of Sulawesi in present day Indonesia, located between Borneo and the Maluku Islands-mainly seafarers and maritime merchants—-they became very influential in the Malayan Peninsula in the 1700s; [17] (p. 31)) from Sulawesi. During this time, Singapore was not mentioned as an active participant in the complex relations of all these parties, but was continuously referred to as a place where trading took place and an attractive place for Chinese and Indian traders to settle. Abshire [16] (p. 35) points out that "While its (Singapore's) fortunes rose and fell and while it may have fallen into relative obscurity as a port, compared to Melaka, Johor, or Bintan Island, some trade activities continued, proving that Singapore was in its ancient history a notable port of call in the globalized trading and shipping networks of the time."

The year 1786 saw the British establish a port in Penang, on the Malay Peninsula, to facilitate their trade with India and China. This led to the eventual move by the British to establish a settlement in Singapore in 1819. According to Miksic [10], Sir Stamford Raffles, rather than "founding" Singapore, "revived an ancient trading port." (p. 20).

\section{History of Toponymic Policies in Singapore}

Perono Cacciafoco and Tuang [17] point out that, while being under the British rule and, then, part of the Federation of Malaya before finally gaining independence, Singapore has experienced a number of transformations in its toponymic policies and many of its place names and street names have been modified or changed completely over time.

Yeoh $[18,19]$ states how (place-)naming practices during the colonial time reflected the ideology of the British rulers, place names commemorated European states-people and public servants and did not reflect local "perceptions and priorities" [19] (p. 300). Haughton [20] (p. 49) reports how at the time when street signs began to appear at street corners in 1887, local Chinese, Malay, and Tamil Singaporeans referred to these places with Chinese, Malay, and Tamil names that were very different to the official ones. This was a custom during the colonial period and is still observed today among older Chinese Singaporeans who do not refer to places using the official names. For example, the suburb of 
Bukit Merah, Malay for "Red Hill", is still known by the Chinese as ang suah, which is Hokkien for "Red Hill" [18,21].

Yeoh also reports [19] that naming practices in the period just after Singapore gained independence (1965) attempted to follow the new nation's vision of treating all the different ethnic groups (Chinese, Malay and Indian) as separate, but also equal and, at the same time, to emphasize a local Malayan identity rather than its colonial past. The Minutes of the Meeting of the Advisory Committee on the Naming of Roads and Streets (1967, cited in [19], p. 301) show a change from the use of the names of prominent public figures to names taken from local flora and fauna and the historical or natural features of the area to be named. However, the local Malay vocabulary was soon exhausted, while, at the same time, this naming practice had many opponents among the Chinese population, who claimed to find the names difficult to pronounce or remember. Yeoh [19] (p. 302) states that "ironically, people preferred road signage and residential addresses in English, the language of the colonial masters, which they perceived as neutral if not superior." This strategy was also perceived as favouring one ethnic group, the Malays, over the others. In 1968, the attempt to use Malay, the National Language of Singapore, as a means to forming a unique identity was dropped in alignment with the new ideology of multilingualism and multiracialism [19] (p. 302). The Jurong Town Council named the streets in a new industrial estate using the theme of "industrialisation" and using the four official languages of the country (in the late 1950s, Singapore adopted English, Malay, Mandarin, and Tamil as official languages) (pp. 33-48). Some examples of names used in this estate are, Enterprise Road or Quality Road in English; Fan Yoong Road and Soon Lee Road, meaning "prosperity" and "progressing smoothly" in Mandarin; the Malay Jalan Pesawat "machinery" and Jalan Tukang "skilled craftsmen"; and the Tamil Neythal Road "to weave".

Another important stage was the establishment of the Committee on the Standardisation of Street Names in Chinese in 1967. This committee's task was to simplify and systematize "existing renderings of street names in Chinese so as to avoid confusions and unhappy transliterations [ ... ] and faithful rendering[s] by sound but should also be elegant and meaningful" (The Straits Times 1970, cited in [19], p. 304). The Street and Building Names Board was established in 2003 and placed under the Urban Redevelopment Authority of Singapore. It "considers and approves the naming and renaming of buildings, estates and streets proposed by building owners and developers." [22] (p. 2).

Singapore today has thousands of toponyms and, with the urban developments, the number of odonyms has increased exponentially [17]. While many appellations display their more modern history, there are a number of place names whose nomenclature and use, when analysed from a historical-geographical perspective, reflect the Sequent Occupance "layout" in Singapore. The next sections will present and discuss a number of such examples.

\section{Sequent Occupance and Diachronic Coexistence in Singapore Toponymy}

A quick look at the multicultural and multilingual society of Singapore, as well as at the history of its urban architecture and landscape, gives the immediate idea of the meaning of Sequent Occupance in the context of the Lion City. Several peoples, in different times and for different reasons, have occupied the island and have cohabited its territory, giving birth, at least in modern times, to a melting pot of cultures able to peacefully coexist and to transform Singapore, over time. Still, besides the skyscrapers and the futuristic skyline that characterize the contemporary city, British colonial buildings, traditional Chinese houses and monuments, Indian temples, ancient streets, and heritage landmarks provide the traveller with the feeling of the crucible of cultures that have made and still make the (relatively) recent history of the Lion City.

In this context, the notion of Sequent Occupance must be necessarily analysed according to a specific - and, probably, specifically Singaporean-key of interpretation that we would like to call "diachronic coexistence". All the cultural and material elements (at the level of heritage), indeed, coexist here and produce a unicum that emblematically witnesses the Sequent Occupance mark of the 
Lion City. However, this Sequent Occupance context cannot be read exactly and comprehensively without taking into account—and studying—its chronology, i.e., its history.

What is contemporary or, better, synchronic, in the urban Singapore context, is actually diachronic, and shows deep historical roots that are different, in their chronology and in their origins. Only by going back in time across centuries and only by considering different timelines, to reconstruct the exact development of the different pieces of this cultural mosaic, scholars can recover and provide an actual picture of this "diachronic coexistence".

This is true not only in the context of the architectural and urban landscape of the Lion City, but also-prevalently - in Singapore's Toponymy, as shown in the following sections of the present study. The coexistence of place names belonging to different cultural and linguistic contexts in the island, producing a truly unique collection of toponyms derived from different roots and attested all together, in the same time and in the same territory, cannot be explained without highlighting the naming processes existing behind those names, sometimes connected with each other, sometimes abruptly -and recently-generated because of governmental resolutions. Historical factors, like settlement dynamics and population movements, with, in relatively recent times, the phenomenon of colonization, are "mixed", therefore, with the language planning strategies of independent Singapore (from 1965), which are reverberated into toponymic policies that have, sometimes, erased the chronology of the naming processes involving whole districts (and, especially, roads and streets) of the Lion City, changing, with a sudden continuity solution, the names-prevalently odonyms—of local areas to others without an apparent historical and/or "traditional" link to the previous Toponymy of those specific areas [17] (pp. 9-30).

The "diachronic coexistence" of place names from different cultural and linguistic contexts, therefore, is not always properly "sequent", in Singapore. However, the historical reconstruction and documentation of governmental choices in the replacement of place names with others through a sudden continuity solution is a valuable hermeneutic process that enables researchers to recover the diachrony of the toponymic changes in the Lion City, isolating "histories" of place names representing a diachronic continuum and other "histories" of toponyms that underwent a sudden substitution connected eminently with language policies and political factors. The two categories of place names coherently coexist, in Singapore, and their histories (and stories) are an irreplaceable part of the local culture and heritage. Their coexistence is "diachronic", because they cannot be explained without a historical study recovering the different timelines and aspects of the naming processes that originated them.

Sometimes, when they have a "traceable history", these names are emblematic of toponymic Sequent Occupance in Singapore; sometimes, when they have been generated "abruptly" by a governmental decision, they show an aspect of "synchronicity" proper of the Sequent Occupance notion. However, these last toponyms could be "deceptive", in a way, since they do not properly belong to a "historical" stratum of the naming process, but they represent, nevertheless, a "historical" stage of local politics and policies. This does not "deny" the historicity of this second category of place names, but highlights their "special" and not completely "diachronic" position in the context of Singapore's toponymic Sequent Occupance.

The following comprehensive sections of the article show the just-mentioned features and aspects of the place names of the Lion City. It is not always simple to assign Singapore's toponyms to one of the two above highlighted categories, because, lato sensu, all the analysed names are, by definition, "historical". However, the distinction between the two categories is represented by the "historical continuity" of the naming processes of these denominations, without an abrupt continuity solution.

A historical research like the one developed in this paper cannot ignore the notion of "Toponymic Stratigraphy" [23] (pp. 29-47), a metaphorically archaeological methodology applied to languages and naming processes reconstructing diachronically different chronological strata of development of a place name over time, over centuries and millennia. Despite that Singapore's context does not always allow the recovery of very remote stages of the naming processes of local place names, an interdisciplinary 
study of ancient chronicles, historical maps, official or private letters by missionaries or colonizers, and archive documents often enables researchers to outline a precise diachronic sequence in the naming of Singapore places or, conversely, to highlight chronological gaps and time periods without historical attestations.

This kind of study on the place names of the Lion City has to be necessarily intensive and qualitative [24] (pp. 65-74), and requires a deep analysis of the selected toponyms both at the linguistic and historical level. Historical maps are, in this context, a very valuable source. The assessment of misspellings or misinterpretations, over time, of local place names by cartographers provides interesting insights into possible different or alternative forms of significant toponyms (to be analysed both diachronically and synchronically) and highlights relevant phenomena of double naming of local place names or of naming and re-naming of local toponyms through the use of two different (and, sometimes, unrelated) languages (e.g., local languages and the colonizers' languages). This linguistic aspect of the toponymic analysis, mainly based on the "cartographic stratigraphy" and historical cartography of Singapore, provides valuable elements to assess the specificity and unicity of the toponymic Sequent Occupance of the Lion City.

\section{Pre-Colonial Toponyms}

Very few places in Singapore exhibit a linear history of Sequent Occupance from before colonial times. As will be discussed in later sections of this article, the majority of the Singaporean toponyms currently in use appeared soon after the British settled on the island and the need to name existing places and new streets and parts of town became compelling and urgent. It is not always clear where most of the names in the early maps came from. That is, were these names already being used by the local inhabitants or did the surveyors name them as needed?

In this section, we will discuss six toponyms that were present on the island before colonial times and we will outline their history up to modern day. Note that there are a number of islands whose names also appear on pre-colonial maps (for example, Pedra Branca and Sentosa—known in very early days as Pulau Blakang Mati), but, due to time constraints, we will not discuss them in this article. The first toponym is Fort Canning Hill, which is perhaps the oldest recorded settlement in Singapore's history. The other five toponyms are found in the 1604 and 1615 maps by the Malay-Portuguese cartographer Manuel Godinho de Erédia $[13,14]$ (p. 374). On these maps are clearly marked the following names:

\begin{tabular}{lc}
\hline Name on Erédia's Maps $(\mathbf{1 6 0 4 , 1 6 1 5 )}$ & Current Names \\
\hline 1. sunebodo & Sungei Bedok (Bedok River) \\
2. tanamera & Tanah Merah \\
3. tanion ru & Tanjong Rhu \\
4. tanion rusa/ruça & Changi \\
5. batu quina & Batu Berlayar \\
\hline
\end{tabular}

\subsection{Fort Canning Hill}

Fort Canning Hill is a 156-foot high hill located at the junction of Canning Rise and Fort Canning Road, Singapore. It is not indicated on Erédia's maps.

One of the earliest attestations of the existence of a settlement on Fort Canning Hill dates to around 1330, when Wang Dayuan [25] reported that, when he visited the island in the 1300s, he found two settlements on Dānmăxi (Temasek). He recorded their names as Long Ya Men "Dragon's Tooth Strait" and Ban Zu. Miksic [10] (p. 177) posits that Ban Zu could be a transliteration of the Malay word pancur, meaning "a spring or stream". Miksic explains that Pancur in Malay is a common place name in coastal Sumatra, Malaysia, and Riau. The name was given to places with clean drinking water, so that sailors could more easily find fresh water when travelling through the region. Wang recounted that Ban 
$\mathrm{Zu}$ was located on a hill, in what is thought to be today's Fort Canning Hill, behind Long Ya Men [10] (pp. 177-183).

According to the Hikayat Abdullah (Hikāyat 'Abdullāh), an autobiography of Abdullah bin Abdul Kadir ('Abdullāh bin 'Abdul Qādir), better known as Munshi Abdullah (Munši' [Munšī, Munšî 'Abdullāh), who was a Malay writer-interpreter hired by Raffles as his secretary and a Malay teacher, written between 1840 and 1843 and published in 1849, the Temenggong, the local Malay Chief, told Colonel Farquhar (the first British Resident and Commandant of colonial Singapore from 1819 to 1823, who accompanied Sir Stamford Raffles on his very first voyage to the island of Singapura in 1819) in 1819 on his visit to Singapura, that a spring of water flowed from the west side of the hill ([26], p. 127; [10], p. 180). The stream was known as pancur larangan, "the forbidden spring". It was thought that the stream was a bathing place for the women of the past ruler who had built a palace on the hill. Because of this and the fact it was the site where a palace had supposedly been built in ancient times and no common men were allowed to ascend it, that it was known by the Malays as Bukit Larangan, "Forbidden Hill" [26] (p. 127). In 1821 John Crawfurd, the second British resident of Singapore, reports seeing the remains of what was reportedly a tomb of a past "ruler" [27]. In 1819, the British built an aqueduct from the stream to supply drinking water to ships visiting Singapore. However, the spring dried up when wells were dug to try and increase the supply of water [10].

Raffles had returned to his position as Lieutenant-Governor in Bencoolen (now Bengkulu City) in Sumatra in 1819, soon after signing the treaty with Tengku Abdul Rahman, the local official or temenggong, who controlled Singapore on behalf of the Sultanate of Riau, to allow the British to establish a settlement in Singapore. In 1822, a small residence was built on the hill for Raffles to live in when he returned to Singapore. The British flag was also raised on the hill on a flagpole at this time, and the hill became known as the Singapore Hill. Raffles' house was extended and restructured by the architect George Dromgold Coleman in 1824 and used as the Government House, thus the hill acquired the name Government Hill. At this time, the place was known by the Chinese in Singapore by its Hokkien name, Ong Ke Swa "Government Hill" [20]. During this period, the Malays began referring to it as Bukit Bendera, "Flag Hill". Later, the hill became known by the Malays as Bukit Tuan Bonham, "Sir Bonham's Hill" after Sir Samuel George Bonham, who was the Governor in Singapore from 1836 to 1848 [28].

The increasing importance of the port and the lack of harbour defences led to the final name change of the hill. The Government House was demolished in 1859, and a military fort was built on the hill. Construction of the fort was completed in 1861, and the building was named Fort Canning, after Viscount Charles John Canning, who was, at that time, the Governor-General and the first Viceroy of India [9]. The hill was thus renamed Fort Canning Hill.

The history of Fort Canning Hill shows its origin as a Malay settlement, transitioning to a colonial outpost and, finally, to its current standing in modern Singapore. Along the way, it has had many different names and its original name did not survive.

\subsection{Sunebodo-Sungei Bedok}

The earliest mention of Bedok is a hydronym sunebodo in Eredia's 1604 and 1615 maps [13,14,29]. Sunebodo is the altered form of the Malay Sungei Bedok "Bedok River" [10]. It appears also in Franklin and Jackson's 1828 map of Singapore, labelled Badok S. (Sungei Badok "River Bedok") [30]. The river still exists today, although now it is a canal, Bedok Canal, and it leads to the Bedok Reservoir.

There are two theories for the origins of the name Bedok. Savage and Yeoh [9] (p. 77) propose that one origin might be from the name of a Malay drum, the bedoh. These drums, before loudspeakers, were used to signal the time of prayer by members of the mosque or to sound alarms. The " $\mathrm{h}$ " sound is pronounced as a glottal stop, written orthographically in Malay as " $\mathrm{k}$ ", hence bedoh became bedok. The other possibility is from the word biduk, which refers to small fishing boats that used to be very common along the Singaporean coastline.

Originally only a hydronym, Bedok, after a period of British Colonization, came to represent a larger area. In a survey map dated 1873 by Wahid Khan, Bedok (spelled here Buddoh) is noted to include 
a large part east of Sungei Bedok (see section on Tanah Merah below). Currently, instead, the river forms the eastern-most boundary of the Bedok planning area. It is a residential neighbourhood with the largest number of residents in the country [31] (pp. 12, 65).

\subsection{Tanamera-Tanah Merah}

Tanah Merah is a geographic area located in the south-eastern coast of Singapore. Its boundary is not clearly defined, but it is agreed upon to be the area east of Bedok (with some overlap) and south-west of Changi. It was originally part of the coastline, but, after the "Great Reclamation" in 1971 [32], the original coast moved "inland" (see section on Tanjong Rusa/Ruça (Changi)).

As mentioned above, the earliest attestation of Tanah Merah is in Eredia's 1604 map, written as Tanamera. The name can also be seen in Eredia's map of 1615. The geographical area depicted in this map is between Tanjung Rusa (see next section) and Sunebodo (see previous section), and corresponds to present day Tanah Merah, although the exact location is difficult to pinpoint due to land reclamation and the ever-expanding area around Changi. Tanah Merah literally means "red land" and it was commonly translated as "Red Cliffs". It was named such by the local people (i.e., the orang laut 'sea people') because of the red laterite hills located on this tract of the coast. The laterites gave the cliffs a reddish colour that was easily seen from the sea, and thus the hills became important navigational landmarks for the orang laut [9] (p. 839).

During precolonial times, other European maps, although not specifically naming this area, provided descriptions of its geography, due to its significance in navigation. For example, in a map by the Portuguese Cartographer André Pereira dos Reis dated 1654, the area was labelled Bareiras Vermelhas "red barriers". Following that, in 1806, a British hydrographic chart, even though it does not name Tanah Merah, depicts hills in the spot where the larger red hill was [33]. British maps marked out the cliffs by their colour, see "Red Cliffs" [34,35] or "Remarkable Red Patch" [36].

During the period of British colonization, maps began identifying two cliffs. A map of Singapore by William Farquhar dated 1822 labels two hills as 1st Red Cliff and 2nd Red Cliff [37,38]. 1st Red Cliff seems to be where the present-day Bedok (as mentioned above) is situated, and 2nd Red Cliff is where today's Tanah Merah is located, but also overlaps with some areas of present-day Changi. Then, in the 1828 map by Franklin and Jackson, the cliffs are marked as Small Red Cliff and Large Red Cliff, respectively [30]. In Thomson's 1842 map, we see both the English names and their Malay translations, Tanah Merah Keechee "Small Red Cliffs" and Tanah Merah Besar "Large Red Cliffs" [39]. An early Chinese name for Tanah Merah was “chi-wo kong" (zhì-hé găng) 致和港 [40], which means something akin to "to peace/heavenly harbour". Probably referring to a safe harbour or a landmark that meant the sailors had reached the port.

Tanah Merah, in both precolonial and colonial times, was seen as not only a navigational landmark, but also an area suitable for military defence. The armada of the Sultan of Johor and a Dutch fleet were stationed near the location and battled the Portuguese who had blockaded the Strait of Johor in 1603 [41]. The Flemish trader Jacques de Coutre, around 1620, proposed that a fort be built "on the east end of the Ysla de la Sabandaria Vieja", which, as mentioned above, was a name for Singapore [10] (p. 408), and Borschberg [42] (p. 116) believes "the east end" is present-day Bedok or Tanah Merah. Prior to World War II, three coastal defence guns were installed at Tanah Merah [43] (pp. 161, 168).

The reclamation works beginning in the 1960s levelled both the hills/cliffs. The area known as Tanah Merah Kechil became incorporated into Bedok, and Tanah Merah Besar is now simply Tanah Merah. Traces of the besar and kechil can still be seen in road names in Bedok, with names like Tanah Merah Besar Road, Tanah Merah Kechil Link, Tanah Merah Kechil Avenue.

\subsection{Tanion ru-Tanjong Rhu}

Tanjong $R h u$ is a commercial and residential area located in central Singapore, and within the Kallang region. Tanjong Rhu houses Singapore's Sports Hub, which includes numerous sports facilities, including the National Stadium and the Singapore Indoor Stadium. 
In Eredia's 1604 map, Tanjong Rhu was written Tanion $R \hat{u}$. Ru comes from the tree grown in the area—casuarina littoria, and locally known to the Malays as pokok rhu [9] (p. 848). Tanjong Rhu means literally, "the cape of the rhu trees". The original location was a sandy spit jutting into the Kallang Basin.

The above-mentioned 1604 map might be the only map documenting Tanjong Rhu in its pre-colonial stages. During the colonial period, the area is frequently labelled as Sandy Point [44]. The Malay name resurfaced alongside the English name in some maps, for example, Tanjong Droo in 1825 [45] and Tanjong Roo in 1842 [39]. The late 1800s and early 1900s saw the point referred to as Tanjong $R u$ [46,47]. The place is also known as Sha tsui to the Chinese, which in Cantonese means "sand pit" [9] (p. 848).

Raffles intended the place to be a marine yard, as evident from Farquhar's letter to Captain Flint in 1822 [48], who went on to start a boat building and repair business (Savage \& Yeoh, 2003), and the area was also known as marine yard [49]. The location soon became a centre for ship-building and a number of shipyards operated from there until the 1980s. After the final phase of the East Coast Reclamation project along the south and eastern coastline in 1977, the old sandy outcrop was completely covered and extended southwards to include what is currently Marina East [32].

\subsection{Tanjong Rusa/Ruça (Changi)}

Changi is Singapore's largest planning area, located in the easternmost part of the island. It is the current location of both Changi Airport and Changi Air Base.

A water colour drawing in História de serviços com martírio de Luís Monteiro Coutinho [29] (p. 49), depicting a maritime battle between Portuguese and Achenese in 1577, labels the Changi we know today as Tanjon Rusa (see [50], p. 122). It appeared as Tanjon Rusa in 1604 on a map by the Malay-Portuguese cartographer Manuel Godinho de Erédia [13]. Several years later, it appeared as Tanion Ruça in a (reconstructed) map dated 1615 attributed to Erédia [14] (p. 374).

It is not clear what the term Rusa refers to. Rusa is Malay for "deer", with Tanjong Rusa meaning "cape of the deer". It might be referring to the Sambar Deer (Rusa unicolor) or the Barking Deer (Muntiacus muntjak), which once roamed the forests of Singapore, but have now decreased significantly due to deforestation and hunting [51]. The term might refer instead to the mousedeer, which resemble the deer, but are not, in fact, "true" deer. Singapore is the home to the lesser mousedeer (Tragulus kanchil) and the greater mousedeer (Tragulus napu) [52]. They are also important characters in Malay folklore, often portrayed as crafty and intelligent animals [53]. However, typically, mousedeer are referred to as kanchil in Malay [53], not as rusa. It might be that rusa is only used when referring to the "true" deer. Mills [54] (p. 225) posits that Rusa might be a variant of the Malay word Kusah. He notes that the shoals off this section of the island's coast were known as Beting Kusah. Beting is Malay for a "shoal or submerged sand bank" and Kusah could be a mispronunciation of susah [55], which means "difficult" or "hard". Another possible meaning is "the dangerous sand-bank" [55] (p. 76). Indeed, there are references to a Beting Kusah, Beting Kusu and a Kampung Beting Kusa in the Changi area [56]. Stubbs [57] states that these places were covered up by the land reclamation projects (1975-2004) that now form Changi Airport. The kampong was cleared out in 1948 to allow a Royal Air Force expansion of the Changi airstrip [58].

The etymology of Changi is disputed, but the generally accepted view is that the name was derived from a botanical "lexical item". The botanical namesakes include the locally grown climbing shrub changi ular (Apama corymbosa), the tall dhengai (Balanscarpus heimii) trees that surround the area in the early 1800s, local timber chengai that were used for buildings and furniture, and the Hopea Sangal tree, which was also known as the Chengal Pasir or Chengal Mata Kuching (Hopea odorata), that also grew in the area once [9]. The first mention seems to be as Tajong Changee in Farquhar's 1822 Survey Map [37], with the north-eastern protruding tip of the area (around today's Nicoll Drive and Changi Coast Road) as Franklin Point, named after the surveyor Captain Franklin [9]. Later, in a map by Congalton and Thomson dated 1846 [59], Franklin Point is labelled as Tanjong Changee, and Tajong Changee as simply Changee. In a map by J.T. Thomson from 1842 [39], Franklin Point and Tanjong Changee are referred to as 
Point Franklin and Tanjong Changi and point to the same place. This is also seen in the 1835 map of Singapore by Heinrich Carl Wilhelm Berghaus [60].

It is worth noting that, in the above mentioned maritime map of 1577 [29] (p. 49), a small island north of Tanjong Rusa was labelled Chani. This island seems to be what is currently known as Tekong Island. Also, in the previously mentioned map of 1615 by Erédia, the group of islands between Singapore and Johor, Pulau Tekong Besar, Pulau Tekong Kechil, Pulau Ubin, etc., is labelled as Pula Chagni [15] (p. 374). Chagni and Chani seem to be phonetically similar to "changi" or variations of it. It is possible the name changi existed before the 1800s, and it referred to the island of Tekong instead. For unknown reasons, the name "migrated" south to the easternmost tip of Singapore, Tanjong Rusa, with this name replaced by Changee and, then, Changi.

\subsection{Batu Quina}

This is an interesting toponym, as the name shows a possible combination of two languages. Batu means "rock" in Malay, and Quina seems to be Portuguese for "corner". Therefore, the name could be translated as "corner stone". Borschberg [14] believes Batu Quina to be the stone formation, or promontory [9], known as Batu Berlayer, that used to be at the western end of the New Harbour. The name appears in literature and in maps in two forms: Berlayer and Berlayar. The agreed origin seems to be Batu Berlayar "sail rock" [9,10]. The name comes from the shape of the outcrop that was said to resemble a sail $[9,10]$. The name Sail Rock can be seen on an 1827 map by Captain Rofs of the Singapore harbour [61].

The name Batu Berlayer can be seen in a number of earlier maps of the area, for example in Berghaus's 1835 map [60]. Other names for this outcrop are Batoo Blyer [45]. Farquhar had noted it down as Batoo Bulaya in 1822 [37] and Franklin and Jackson noted it down as Batu Balayan in 1828 [30]. Thomson's 1842 map shows this as Sinki Point or Batoo Beylayer [39]. In his 1846 map, he has it as Batu Berlayer and Lots Wife. As early as 1709, British travellers had named this rocky pinnacle as "Lott's wife" [10] (pp. 145, 176). While in Thomson's map with Samuel Congalton from the same year, he reports the cape as Sinki Point and the rock as both Lots Wife or Batu Berlayer [59]. Here he also has a small river nearby called Sungei Batu Berlayer, which seems to be the current Berlayer Creek. A 1907 map shows this point both as Berlayer Point and Lots Wife [62] and, in the 1914 map by Wagner and Debes, it appears as Tanjong Blayer and Lot's Wife [46]. The rocky formation was blown up by the British in 1848 to improve the passage of ships through the harbour [9].

The name of this rock formation has been connected with the account (see section on Fort Canning Hill) by the Chinese traveller Wang Dayuan, who sailed through the area and noted down Long Ya Men (Lóng Yá Mén) "Dragon's Tooth Strait" or "Dragon's Tooth Gate" as one of two settlements on the island $[7,9,10,25]$.

The name Berlayer was given to a road, Bukit Berlayer Road (this road now does not exist anymore) and to two villages, Kampong Berlayer and Batu Berlayer Village, in 1922 [9] (p. 113). The area has undergone a number of redevelopments with the road, the kampong and the village being closed. Berlayer is used for the aforementioned Berlayer Creek, while Berlayar is utilised for the Berlayar Beacon, a naval beacon built in the 1930s, and for the Berlayar Canal. All these locations, very near to each other, are in the same Labrador Park area.

\section{Other Noteworthy Toponyms of Singapore}

It is a fact that the majority of the toponyms in Singapore cannot boast a history as long as those discussed above, and that newer, more modern naming practices reflect the complex societal make-up of the Lion City. It is also true that many toponyms have very interesting histories that reveal the multi-faceted cultural context of Singapore. Some of them will be discussed below. 


\subsection{Chulia Street}

The original name of Chulia Street was Kling Street. Kling is generally thought to be a form of the term "Kalinga" or to be translatable as "men from Kalinga", in Malay orang kling [9] (p. 176). Kalinga was an ancient Indian kingdom (3rd Century to the 11th Century) that had substantial dealings with and influences on Southeast Asia $[63,64]$. This led to the word keling/kling in Bazaar Malay to be used to refer to Indian people $[18,65,66]$. Pieris [67] (p. 90) states that the "Indians in the Straits were typically identified as Chulias after the Southern Chola Kingdom in Tamil Nadu and Klings after the Kalinga kingdom centered in the region of Orissa. The geographic reach of these kingdoms, however, makes it difficult to identify particular ethnic groups geographically, and are certainly indistinct within modern Tamil diaspora. Tamils were first identified as a category in the 1887-88 Blue Book Report on the Straits Settlements."

Velayutham [66] (p. 263) and Pieris [67] (p. 79) also report that another origin of the term kling may be from the sounds made by the ankle chains on Indian convict labourers at the time of Singapore's founding as a British colony. Velayutham [66] (p. 263) also goes on to say that, because of the association with convicts, keling and its derivations keling-kia and keling kwai "devil/ghost" acquired negative connotations and were found to be offensive.

How Kling Street acquired its official name is not clear. Abdul Rahman and Cornelius [65], and see also [9] (p. 481), posit that the street was known as such because of the high concentration of Indians living and working there, and the non-Malay settlers, having heard the Malays referring to the Indians as klings, adopted the term. Hence, people referred to it as Kling Street, which the town planners must have kept.

In 1921, the Indian Association of Singapore petitioned for the derogatory term kling to be changed and the street to be renamed King Street. The name was instead changed to Chulia Street in honour of the large Indian population in Singapore at the time [68,69]. The change of name became effective on 1 January 1922 [70]. Interestingly, in 1972, Jalan Besi Baja was renamed to Tanjong Kling Road [9] (p. 831).

The Chinese knew this street as Swa Kia Teng "Small hill top", or Thi Thiau Kha "The foot of the iron pillars" [20] (p. 57). The reason for the latter name was, reportedly, due to the many iron pillars that were used in the construction of houses in the street [9]. The Tamil name for the street was Kathi Kadei Sadakku "Knife shop street", while the Malay name was Jalan Kedei Pisau, which also meant "Knife shop street" [20,65].

\subsection{Mount Sophia}

Mount Sophia is a hill located north of Fort Canning Hill. "Mount Sophia" is the name for both the hill and the road leading up to it. Currently, it is a middle to upper-class residential neighbourhood, and has been since the 1800s [71]. The hill was originally known as Bukit Selegie. A map from around 1820-1822, made by the Dutch [72], presented the hill as Bukit Silige. In Farquhar's letter to Raffles written on 23 December 1822, we can read,

...the first hill lying to the northward of the Government Hill is that of Silligie, which on clearing the country at the commencement of the establishment, was found to be occupied on the western side by a Chinese Planter, who had formed a Gambier Plantation there, the eastern half of the hill is at present occupied by Captain Flint \& was a primitive forest which I caused to be partially cleared at the Government expense, to the extent of about 33 acres.

In the coming years, the location was labelled Bukit Selegie in a survey map of 1822-23 [44] and Bukit Silegy in 1825 [45]. In Coleman's 1836 map [73], however, the hill was marked as Mount Sophia, with the adjacent hill, Mount Emily, as Bukit Seligie.

The etymology of selegie is disputed. Savage and Yeoh [9] propose several options for the name. Selegie could have been named after a famous Bugis pirate chief. The Bugis people who lived around the area were also named after him as orang selegie. A second theory posits a wooden spear to be the Selegie. Haughton [20] (p. 60) suggests "sĕligi", which is Malay for a "wooden dart". Selegie is also seen 
as a variant of seligi, which refers to "nibong palm used in flooring and fishing stakes" in Malay [9] (pp. 594, 758). This last one might be the most plausible, as the seligi is said to be made from bamboo, or from nibong palm or sago wood [74] (p. 728). Bamboo was very abundant at the foot of the hill, so much so that the Chinese called the area Tek Kia Kha "the foot of the small bamboos" [75]. The reason why this weapon would be associated with the hill is unknown, but it may have something to do with the events of Iskandar Shah fleeing Temasik in 1377 via the road at the foot of the hill, now known as Selegie Road (the Sejarah Melayu refers to Iskandar Shah as Sri Sultan Iskandar Shah and claims that he ruled Singapura for three years. He fled Singapura when the Javanese attacked Singapura, and eventually established Melaka). Maybe, according to a version of the story, the king carried the weapon at the time. Seligi is also the name of a javelin used by the Orang Suku Laut of Riau for fishing [76] (p. 145). These Orang Laut (also known as sea-gypsies) were seen spearing fish in the Straits of Singapore during the 16th century [15]. In the Hikayat Abdullah, they were said to have brought fish for the Temenggong to eat, and that spearing fish was their main method of fishing, "that they knew no other way" [77] (p. 121). Whether it is named after a local or foreign object, the name seligi seems to be describing the feature of the hill, relating it to the prongs on a spear or dart.

The first appearance of an anglicized name for the hill is Coleman's 1836 map mentioned above, where Bukit Selegie is labelled as Mount Sophia. Where the name "Sophia" comes from is also disputed [9], as a number of "Sophias" have been posited as the origin of the toponym. One widely accepted version is that the hill was named after Raffles' second wife, Sophia Raffles. The hill could also have been named in honour of Mary Sophia Anne, the daughter of Captain William Flint, who resided on the hill. Merchant Charles Robert Prinsep's daughter Sophia is also believed to be the namesake, as he named two other adjacent hills after his daughters (Emily and Catherine), when he bought 217 acres of land in the Selegi area in 1831 [9]. As if three Sophias were not enough, people believe missionaries Sophia Cook and Sophia Blackmore could also have been the source of the name [71].

As Captain Flint lived on the hill at the end of 1823, the hill is also referred to as Flint's Hill [78].

\subsection{Stamford Canal and Bras Basah Road}

Stamford Canal is a concrete drain located in front of the former Cathay Building at Handy Road. This is the only visible portion of the canal today, with its lower course flowing in an artificial underground, beneath buildings and pedestrian malls. The canal was originally a five kilometre long river, running from the Istana to Marina Bay [10] (p. 210). It provided water to the orchards which Orchard Road once led to in the 19th century, and the site for dhobis "washer men", which eventually became the namesake for the location in Singapore currently known as Dhoby Ghaut [9] (p. 227).

The "canal" went by many names over time, with the first being associated with its freshwater nature. In the Plan of Singapore Harbour by Captain Daniel Rofs of 1819 [79], the river was marked as a "fresh water" river, but it was not yet named (judging by another river indicated as Red River, this "fresh water" marking is not likely a name). The first attested naming of the river as Fresh Water River is from the map dated 1822 by William Farquhar mentioned above [37]. From a journal entry dated 3 February 1822, we know that John Crawfurd made a stop in Singapore during his diplomatic mission in Siam. While walking near Fort Canning, he came across a Malay wall, and "a little rivulet running at the foot of it, and forming a kind of a moat." [27] (p. 69), but no name was mentioned. In letters from Farquhar to Lieutenant L.N. Hull, Acting Secretary to Raffles, dated March 1823, he used both "fresh water stream" and "fresh water rivulet" to refer to the same river [80,81]. A map from 1825 confirms again the name Fresh Water River [45]. In 1828, it was known as Fresh water Rivulet [49]. The map of Singapore by Heinrich Carl Wilhelm Berghaus, from 1835, labels the river, in German, as Frischwasser "Freshwater" [60].

The river appeared as Sungei Brass Bassa in the 1846 town plan by John T. Thomson [82]. Brass Bassa is the anglicized spelling of Malay beras basah "wet rice" (see Bras Basah Road below). The popular etymology tells that rice brought in from boats sailing into the area through the river were laid on the river banks to dry, but, during high tides, the rice would get wet, hence "wet rice". Another more credible alternative comes from an article in The Straits Times Weekly [83], mentioning that rice brought 
in by boats commonly became saturated and rotten and, in turn, produced a horrible smell. To counter this problem, by law all the wet and decaying rice from the ships was to be laid out to dry in a spot out of the (then) town, hence the name Brassbassa Road. It is likely that the name was first given to the road where people dried the rice, rather than the river. This can be seen from maps prior to 1846, where Brass Bassa Road was labelled, and the river was not.

There was a brief period where the river was known as Raffles River [84] (p. 57), due to its proximity to the Raffles Institution.

The river was canalized sometime in the late 19th Century and renamed Stamford Canal, after Sir Stamford Raffles (and maybe to couple with Stamford Road, to which it flows parallel). The canal back then was still open for all to see, and several bridges were constructed perpendicular to it. These include Polglase Bridge on North Bridge Road, Malcolm Bridge on Victoria Street, Stamford Bridge on the now Nicoll Highway, and Institution Bridge which connects Beach Road and Connaught Drive. Flooding of the canal was very common, and, somewhat less so, it still is; therefore, the Chinese gave Stamford Road the nickname lau-chui khe in Hokkien, meaning "flowing water road" [9]. It was often reported to be very foul smelling and stagnant ([9], p. 806; [40], p. 130). Efforts to beautify the urban environment were carried out and the canal was covered up [71]. All the above-mentioned bridges have all been demolished because of this. Aside from the small visible part of the canal near the Cathay Building, the only other indication of its existence is a small black-painted iron plaque on stone structures situated on the north side of Stamford Road, opposite the Singapore Sports Club. It commemorates the now defunct Stamford Bridge, and the "invisible" Stamford Canal that runs beneath the walkways.

The first appearance on maps of Bras Basah Road dates back to Coleman's 1836 survey, as Brass Bassa Road [73]. Prior to that, in the 1820s (see [49]), the road was divided into two parts: Church Street (between Beach Road and North Bridge Road) and Selegy Street (from North Bridge Road to Selegie Road). Church Street owes its name to the London Missionary Society Chapel, which occupied the corner of North Bridge Road and Bras Basah Road from 1819 till 1847 [9]. Selegy Street was named after Bukit Selegie (Mount Sophia), mentioned above. It was also known to Raffles as College Street, due to the presence of the Raffles Institute beside it [85].

Bras Basah Road was built by convicts from British India [9]. As the jail housing these Indian convicts was situated between Bras Basah Road and Stamford Road, Chinese people referred to this road by many names. Initially, as lau kha ku keng khau (lău khâ kū kêng kháu) (老脚拘间口) “Mouth of the Old Jail” [20,40], in Hokkien, and Kau ka-ku hau ( $g a u^{6} g a a^{3} g u^{2} h a u^{2}$ ) (旧架古口), in Cantonese. kha $k u$ and $k a-k u$ here mean "ankle chains". As it was part of the European town, there were numerous European businesses and landmarks near the road, and these became the inspiration for the other names by Chinese people: he lan xi li bai tang (hélánxī lỉbàitáng) (和兰西礼拜堂) “beside the French church", in Hokkien, referencing to the Catholic Cathedral of the Good Shepherd; tek kok seng nong (tèk kòk sǐn lóng) (德国神农) “the German pharmacy”, due to a German-owned pharmacy nearby; Hai ki ang-neo toa-oh pi (háik ǎngmó tŏa ô pă) (海墘红毛大学边) (The Chinese characters indicate that this should 'ang mo' 红毛. However, both [9] and [40] record this as 'ang neo'. This inconsistency could be either a transliteration error or a translation error, most likely the former.) "beside the seaside English big school", referencing to the Raffles Institution. It was also known for a Hakka-owned tailoring business, as seen from the name Thong Kwong Sen kei "Thong Kwong Sen Street" [9,40].

\section{Conclusions}

This paper aimed to investigate the applicability of the notion of Sequent Occupance to the Singapore context through the study of Singapore Toponomastics. The analysis, carried out on ten local toponyms, does give us an insight into the diachronic and synchronic development of Singapore urban Toponymy. What the results of this work show us is that the influences of all the cultures which have "sequentially" occupied Singapore from the past to the present can be seen in the history of its place names. Some places underwent numerous changes in their names before settling to what we see today. None of the pre-colonial toponyms were resilient to the socio-political forces at play 
and remained as originally named. Singapore's multilingual and multicultural nature is played out in many different ways. However, it is inevitable that, since the city was planned and built during colonial times, its naming practices seem to be firmly linked to its colonial past. The place names in Singapore reflect a willingness by the colonial masters at first, and the new independent government later, to accommodate this diversity in the toponyms and odonyms of this now very international city.

The cultural imprint of each group that lived or passed through Singapore is, indeed, never completely lost, and its traces in toponyms can be seen to the present day. However, as mentioned above, the study of the place names of the Lion City has to be conducted always taking into account the different chronologies and timelines of the related individual naming processes, in order to reconstruct and provide a stratigraphy of names highlighting the different roots and origins of the place names currently constituting the whole existing set of Singapore's toponyms. The synchronic, actual "big picture" of the contemporary local place names in the Lion City, definitely showing the Sequent Occupance of these denominations, finds in the historical study of their roots and diachronic development its comprehensive explanation and, at the same time, shows its nature of an etymological puzzle and a series of onomastic gaps that still need to be filled.

The article highlights, therefore, through the analysis of local place names, the historical processes in the "making" of the multi-layered Singapore society, from pre-colonial times to the contemporary Lion City. Our analysis shows how the current landscape of local toponyms, alongside its architectural landscape, is interpretable through Sequent Occupance principles, in an urban environment where synchronic elements have to be studied both in their current, contemporary context and through the reconstruction of their historical origins. In all, our study provides an effective and reliable analysis of the complex historical and cultural processes at play in the old and new Singapore.

Author Contributions: Conceptualization, F.P.C. and F.C.; Writing-original draft preparation, F.C., Z.X.T. and F.P.C.; Writing-review \& editing, F.C. and F.P.C.; Archival Research, Z.X.T.

Funding: This work was supported by the AcRF Tier 1 Research Project 2017-T1-002-193 (Perono Cacciafoco), Nanyang Technological University, Singapore.

Conflicts of Interest: "The authors declare no conflict of interest."

\section{References and Notes}

1. Hanks, R.R. Encyclopedia of Geography Terms, Themes, and Concepts; ABC-CLIO, LLC: Santa Barbara, CA, USA, 2011.

2. Denevan, W.M. Introduction. In Carl Sauer on Culture and Landscape: Readings and Commentaries; Denevan, W.M., Mathewson, K., Eds.; Louisiana State University Press: Baton Rouge, LA, USA, 2009; pp. 89-95.

3. Denevan, W.M.; Mathewson, K. Carl Sauer on Culture and Landscape: Readings and Commentaries; Louisiana State University Press: Baton Rouge, LA, USA, 2009.

4. Whittlesey, D. Sequent occupance. Ann. Assoc. Am. Geogr. 1929, 19, 162-165. [CrossRef]

5. Meyer, A.H. Toponomy in sequent occupance geography, calumet region, indiana-illinois. Proc. Indiana Acad. Sci. 1944, 54, 142-159.

6. Hsü, Y.-T. Singapore in the remote past. J. Malay. Branch R. Asiat. Soc. 1972, 45, 1-9.

7. Braddell, R. Lung-ya-men and Tan-ma-hsi. J.Malay. Branch R. Asiat. Soc. 1950, 23, 37-51.

8. Gerini, G.E. The nagarakretagama list of countries on the indo-Chinese Mainland (Circâ 1380 A.D.). J. R. Asiat. Soc. Great Br. Irel. 1905, 1905, 485-511. [CrossRef]

9. Savage, V.R.; Yeoh, B.S.A. Singapore Street Names: A Study of Toponymics; Marshall Cavendish: Singapore, 2003.

10. Miksic, J.N. Singapore E the Silk Road of the Sea, 1300-1800; National University of Singapore Press and the National Museum of Singapore: Singapore, 2013.

11. Winstedt, R.O. A History of Malaya; Marican \& Sons: Kuala Lumpur, Malaysia, 1982.

12. Borschberg, P. History of Singapore: Portuguese \& Dutch Sources; Institute of Southeast Asian Studies (ISEAS)—Yusof Ishak Institute: Singapore, 2018. 
13. Abdul Rahman, N.-A. A Portuguese Map of Sincapura. Biblioasia, Features. Available online: http: //www.nlb.gov.sg/biblioasia/2016/01/22/a-portuguese-map-of-singapura/ (accessed on 14 July 2019).

14. Borschberg, P. Singapore and its Straits, c.1500-1800. Indones. Malay World 2017, 45, 373-390. [CrossRef]

15. Borschberg, P. Jacques de Coutre's Singapore and Johor 1594-c.1625; National University of Singapore Press: Singapore, 2014.

16. Abshire Jean, E. The History of Singapore; Greenwood: Santa Barbara, CA, USA, 2011.

17. Perono Cacciafoco, F.; Tuang, S.Q. Voices from the Streets: Trends in naming practices of Singapore odonymy. Rev. Hist. Geogr. Toponomast. 2018, XIII, 9-30.

18. Yeoh, B.S.A. Street names in colonial Singapore. Geogr. Rev. 1992, 82, 313-222. [CrossRef]

19. Yeoh, B.S.A. Street-naming and nation-building: Toponymic inscriptions of nationhood in Singapore. Area 1996, 28, 298-307.

20. Haughton, H.T. Native names of streets in Singapore. J. Malay. Branch R. Asiat. Soc. 1891, 6, 49-65.

21. Yeh, Y.-T. "Erased place names" and nation-building: A case study of Singaporean toponyms. In Asia-Pacific Forum No. 59; Chu, T.-L., Ed.; Research Center for Humanities and Social Sciences, Academia Sinica: Taipei, Taiwan, 2013; pp. 119-156.

22. Board, S.A.B.N. Handbook on Guidelines for Naming of Streets; Urban Redevelopment Authority: Singapore, 2017.

23. Perono Cacciafoco, F.; Cavallaro, F.P.; Kratochvíl, F. Diachronic toponomastics and language reconstruction in South-East Asia according to an experimental convergent methodology: Abui as a case-study. Rev. Hist. Geogr. Toponomast. 2015, X, 29-47.

24. Tent, J. Approaches to research in toponymy. Names J. Onomast. 2015, 63, 65-74. [CrossRef]

25. Wheatley, P. The Golden Khersonese: Studies in the Historical Geography of the Malay Peninsula before A.D. 1500; University of Malaya Press: Kuala Lumpur, Malaysia, 1961.

26. Hill, A. The Hikayat Abdullah. J. Malay. Branch R. Asiat. Soc. 1955, 28, 3-354.

27. Crawfurd, J. Journal of an Embassy from the Governor-general of India to the Courts of Siam and Cochin China: Exhibiting a View of the Actual State of Those Kingdoms, Volume 1; H. Colburn and R. Bentley: London, UK, 1830.

28. Cornelius-Takahama, V. Fort Canning Park. Infopedia. Available online: http://eresources.nlb.gov.sg/ infopedia/articles/SIP_8_2004-12-10.html (accessed on 10 June 2019).

29. Erédia, M.G.d. História de serviços com martírio de Luís Monteiro Coutinho; Goa, India, 1615.

30. Franklin, J.; Jackson, P. Plan of the British Settlement of Singapore. In Wikimedia Commons; Henry Colburn: London, UK, 1828; Available online: https://upload.wikimedia.org/wikipedia/commons/4/44/Plan_of_the_ British_settlement_of_Singapore_published_1828.jpg (accessed on 21 June 2019).

31. Department of Statistics. Population Trends 2018. Available online: https://www.singstat.gov.sg/-/media/ files/publications/population/population2018.pdf (accessed on 17 May 2019).

32. Lim, T.S. Land from Sand: Singapore's Reclamation Story. Biblioasia, Features. Available online: http://www. nlb.gov.sg/biblioasia/2017/04/04/land-from-sand-singapores-reclamation-story/ (accessed on 15 July 2019).

33. Thomas, E.R.N. Chart of the Straits of Singapore. In National Archives of Singapore; A. Dalrymple: London, UK, 1806.

34. Horsburgh, J. Strait of Malacca 1806 Sheet 2. In National Library Board Singapore; James Horsburgh: London, UK, 1806.

35. A plan of soundings from pulo aor to the southward and outside of the reef off point Romania towards the entrance of Sincapour strait. In National Archives of Singapore; James Horsburgh: London, UK, 1812.

36. Tho, E. New survey of the straits of Singapore from Pulo Pesang to Bintang Hill. In National Archives of Singapore; Rob. Laurie and JA Whittle: London, UK, 1807.

37. Farquhar, W. Plan of the island of Singapore, including the new British Settlement and adjacent Islands. In National Library Board Singapore; 1822. Available online: http://eresources.nlb.gov.sg/printheritage/ detailmap/e60e3d92-2da5-4d6d-a02e-44da321e6684.aspx (accessed on 21 June 2019).

38. Murray, J. Sketch of the island of Singapore. In Wikimedia Commons; 1830; Available online: https: //commons.wikimedia.org/wiki/File:Singapore_1830_map_by_John_Murray.jpg (accessed on 17 July 2019).

39. Thomson, J.T. Straits of Singapore. In National Archives of Singapore; 1842. Available online: http://www.nas.gov.sg/archivesonline/watermark/cards/jpgcd/20050000923/img0095_Singapore_ S_13_D2018_000217_RGS.jpg (accessed on 17 July 2019).

40. Firmstone, H.W. Chinese names of streets and places in Singapore and the Malay Peninsula. J. Straits Branch R. Asiat. Soc. 1905, 42, 53-208. 
41. Borschberg, P. The Singapore and Melaka Straits: Violence, Security and Diplomacy in the 17th Century; National University of Singapore Press: Singapore, 2010.

42. Borschberg, P. Remapping the straits of Singapore. New insights from old sources? In Iberians in the Singapore-Melaka Area and Adjacent Regions (16th to 18th Century); Borschberg, P., Ed.; Otto Harrassowitz Verlag: Wiesbaden, Germany, 2004; pp. 93-130.

43. Murfett, M.H.; Miksic, J.; Farell, B.; Chiang, M.S. Between Two Oceans: A Military History of Singapore from 1275 to 1971, 2nd ed.; Marshall Cavendish International (Asia): Singapore, 2011.

44. Singapore 1822-3. In National Archives of Singapore; 1822-1823. Available online: http://www.nas.gov.sg/ archivesonline/maps_building_plans/record-details/fa3d03c7-115c-11e3-83d5-0050568939ad (accessed on 17 July 2019).

45. Part of Singapore Island. In National Archives of Singapore; 1825. Available online: http://www.nas.gov.sg/ archivesonline/maps_building_plans/record-details/fb6eb3fd-115c-11e3-83d5-0050568939ad (accessed on 17 July 2019).

46. Wagner, H.; Debes, E. Map of the city of Singapore, ca 1914. In Wikimedia Commons; Verlag Karl Baedeker: Leipzig, Germany, 1914.

47. Keppel, H. A map of Singapore island from A Sailor's Life under Four Sovereigns. In Wikimedia Commons; Macmillan and Co: London, UK, 1899.

48. Farquhar, W. No. 29 to Captain Flint. Singapore. 1822. Available online: http://www.nas.gov.sg/archivesonline/ private_records/record-details/79707403-02a0-11e9-bebd-001a4a5ba61b (accessed on 7 July 2019).

49. Jackson, P. Plan of the Town of Singapore. In National Archives of Singapore; Philip Jackson: London, UK, 1828.

50. de Sousa Pinto, P.J. The Portuguese and the Straits of Melaka, 1575-1619: Power, Trade and Diplomacy; National University of Singapore Press: Singapore, 2012.

51. Goh, L.K. When Tigers Used to Roam: Nature \& Environment in Singapore. Biblioasia, Features. Available online: http://www.nlb.gov.sg/biblioasia/2018/01/10/when-tigers-used-to-roam-nature-environment-insingapore/ (accessed on 29 June 2019).

52. The Biodiversity of Singapore. Tragulus Napu. Available online: https://singapore.biodiversity.online/ species/A-Vert-Mammalia-000006 (accessed on 6 July 2019).

53. Pwee, T. Mousedeer. Infopedia. Available online: http://eresources.nlb.gov.sg/infopedia/articles/SIP_1527_ 2009-05-21.html (accessed on 29 June 2019).

54. Mills, J.V. Eredia's description of Malacca, Meridional India, and Cathay. Translated from the Portuguese, with notes. J. Malay. Branch R. Asiat. Soc. 1930, III, 1-288.

55. Haughton, H.T. Notes on names of places in the island of Singapore and its Vicinity. J. Straits Branch R. Asiat. Soc. 1889, 20, 75-82.

56. Chen, J.; Chong, K.Y.; Yee, A.T.K.; Tan, H.T.W. A Gazetteer of the Singapore Locality Names of the Collections of the Herbarium, Singapore Botanic Gardens; Lee Kong Chian Natural History Museum, National University of Singapore: Singapore, 2014.

57. Stubbs, P. Fort Siloso: Beting Kusah 6 Inch Battery. Available online: http://www.fortsiloso.com/batteries/ wwII/kusah/bk.htm (accessed on 6 July 2019).

58. Lim, J. A Changi Well Hidden from Sight. Available online: https://thelongnwindingroad.wordpress.com/ tag/changi-beach/ (accessed on 7 July 2019).

59. Congalton, S.; Thomson, J.T. This survey of the straits of Singapore, is respectfully inscribed to the honourable Colonel Butterworth, C.B. In National Archives of Singapore; James M. Richardson: London, UK, 1846. Available online: http://www.nas.gov.sg/archivesonline/maps_building_plans/record-details/fbcc9cfc-115c11e3-83d5-0050568939ad (accessed on 21 June 2019).

60. Berghaus, H.C.W. The oldest German map of Singapore. In National Archives of Singapore; Justus Perthes: Gotha, Germany, 1835. Available online: http://www.nas.gov.sg/archivesonline/maps_building_plans/recorddetails/fb47bb81-115c-11e3-83d5-0050568939ad (accessed on 21 June 2019).

61. Rofs, D. A plan of the harbour near Singapore. In Wikimedia Commons; 1827; Available online: https://commons.wikimedia.org/wiki/Category:19th-century_maps_of_Singapore\#/media/File:A_plan_of_ the_harbour_near_Singapore_by_Captn_Dl_Ross_FRS_Marine_Surveyor_General_1827_RMG_F0386.tiff (accessed on 17 July 2019).

62. Singapore railways. In Wikimedia Commons; 1907; Available online: https://upload.wikimedia.org/wikipedia/ commons/7/7a/Singapore_Railways\%2C_1907.jpg (accessed on 17 July 2019). 
63. Mohanty, P.C. Maritime trade of ancient Kalinga. Orissa Rev. 2011, 2011, 40-42.

64. Patra, B. Kalinga in South East Asia. Orissa Rev. 2004, 2004, 9-16.

65. Abdul Rahman, N.-A.; Cornelius, V. Chulia Street. Available online: http://eresources.nlb.gov.sg/infopedia/ articles/SIP_222_2005-01-18.html (accessed on 6 July 2019).

66. Velayutham, S. Everyday racism in Singapore. In Everyday Multiculturalism; Wise, A., Velayutham, S., Eds.; Palgrave Macmillan: London, UK, 2009; pp. 255-273.

67. Pieris, A. On dropping bricks and other disconcerting subjects: Unearthing convict histories in Singapore. Fabrications 2005, 15, 77-93. [CrossRef]

68. Peet, G.L. Rickshaw Reporter; Eastern University Press: Singapore, 1985.

69. Municipal Matters. Malaya Tribune, 25 June 1921, p. 5. Available online: http://eresources.nlb.gov.sg/ newspapers/Digitised/Article/maltribune19210625-19210621.19210622.19210617 (accessed on 17 July 2019).

70. Manchester, H.L. Municipal notice. The Straits Times, 1 August 1921, p. 16. Available online: http://eresources. nlb.gov.sg/newspapers/Digitised/Article/straitstimes19210801.19210802.19210100.19210805 (accessed on 17 July 2019).

71. Cornelius, V. Stamford Road. Infopedia. Available online: http://eresources.nlb.gov.sg/infopedia/articles/ SIP_865_2005-01-24.html (accessed on 26 June 2019).

72. Map of Singapore and environment (draft). In National Archives of Singapore; 1820-1822. Available online: http://www.nas.gov.sg/archivesonline/maps_building_plans/record-details/faea412e-115c-11e3-83d50050568939ad (accessed on 17 July 2019).

73. Coleman, G.D.; Tassin, J.B. Map of the town and environs of Singapore. In National Archives of Singapore; 1836. Available online: http://www.nas.gov.sg/archivesonline/maps_building_plans/record-details/f96ffb35115c-11e3-83d5-0050568939ad (accessed on 21 June 2019).

74. Edwards, E.D.; Blagden, C.O. A Chinese vocabulary of Malacca Malay words and phrases collected between A.D. 1403 and 1511. Bull. Sch. Orient. Afr. Stud. 1931, 6, 715-749. [CrossRef]

75. Mohd Nasir, H. Selegie Road. Infopedia. Available online: http://eresources.nlb.gov.sg/infopedia/articles/ SIP_586_2004-12-30.html (accessed on 1 July 2019).

76. Chou, C. The Orang Suku Laut of Riau, Indonesia: The inalienable gift of territory; Routledge: London, UK; New York, NY, USA, 2009.

77. Shellabear, W.G. The Autobiography of Munshi Abdullah; Methodist Publishing House: Singapore, 1918.

78. Singapore. Singapore Chronicle and Commercial Register, 26 May 1831, p. 3. Available online: http: //eresources.nlb.gov.sg/newspapers/Digitised/Article/singchronicle18310526-1.2.9 (accessed on 21 June 1919).

79. Rofs, D. Plan of Singapore Harbour. In National Archives of Singapore; James Horsburgh: London, UK, 1819.

80. Farquhar, W. No. 178 to Lieutenant L.N. Hull Acting Secretary to the Lieutenant Governor. Singapore. March 1823. Available online: http://www.nas.gov.sg/archivesonline/private_records/Flipviewer/prism_publish/9/ 9b5dea37-0a73-11e9-9481-001a4a5ba61b-4081/web/html5/index.html?launchlogo=tablet/PrivateRecords_ brandingLogo_.png\&pn=1 (accessed on 10 July 2019).

81. Farquhar, W. No. 179 to Messrs Bonham. Singapore. March 1823. Available online: http: //www.nas.gov.sg/archivesonline/private_records/Flipviewer/prism_publish/9/9b5f37cd-0a73-11e9-9481001a4a5ba61b-4082/web/html5/index.html?launchlogo=tablet/PrivateRecords_brandingLogo_.png\&pn=1 (accessed on 15 June 2019).

82. Thomson, J.T. Singapore town. In National Archives of Singapore; J.M. Richardson: London, UK, 1846.

83. The night soil carriers. Straits Times Weekly, 16 February 1892, p. 4. Available online: http://eresources.nlb. gov.sg/newspapers/Digitised/Article/stweekly18920216-1.2.23 (accessed on 19 June 2019).

84. Tyers, R.K. Singapore: Then and Now; Landmark Books: Singapore, 1993.

85. J.B.N. Raffles College-Old and New! The Singapore Free Press and Mercantile Advertiser, 21 June 1928 , p 1. Available online: http://eresources.nlb.gov.sg/newspapers/Digitised/Article/singfreepressb19280621-1.2.3 (accessed on 12 July 2019).

(C) 2019 by the authors. Licensee MDPI, Basel, Switzerland. This article is an open access article distributed under the terms and conditions of the Creative Commons Attribution (CC BY) license (http://creativecommons.org/licenses/by/4.0/). 